\title{
THE EFFECT OF ATROPINE UPON THE ABSORPTION OF VITAMIN A
}

\author{
By F. J. INGELFINGER, R. E. MOSS, AND J. D. HELM, JR. \\ (From the Evans Memorial, Massachusetts Memorial Hospitals, and the Department of \\ Medicine, Boston University School of Medicine, Boston)
}

(Received for publication March 22, 1943)

Records of the small intestinal motor activity in patients with sprue show that the tone is greatly reduced, that the large (L) waves are absent for long periods of time, and that the small (S) waves tend to be of diminished amplitude (1). A very similar record is obtained from the gut of a normal person who has been given atropine (2), a similarity which is apparent in Figure 1.

Evidence has lately been presented that the absorption defect in sprue-like states is in part dependent upon the abnormal intestinal motor activity which characterizes these disorders (3). If this concept is true, the changes in intestinal motility which follow atropinization might also affect the absorption rate of foodstuffs from the bowel. In order to test this hypothesis, vitamin A absorption tests were carried out in experimental subjects before and after atropinization.

\section{METHODS}

Twenty-three vitamin A absorption tests were done in 6 subjects, of whom 3 were normal volunteers and 3 , hospital patients without active organic disease of the gastrointestinal tract or liver. In 19 experiments, the test substance, consisting of $5 \mathrm{cc}$. of Navitol ${ }^{1}$ (250,000 I.U. of vitamin $A$ ), was injected directly into the small intestine.

1 Supplied by E. R. Squibb \& Sons.

\section{RECORDS OF JEJUNAL MOTOR ACTIVITY}
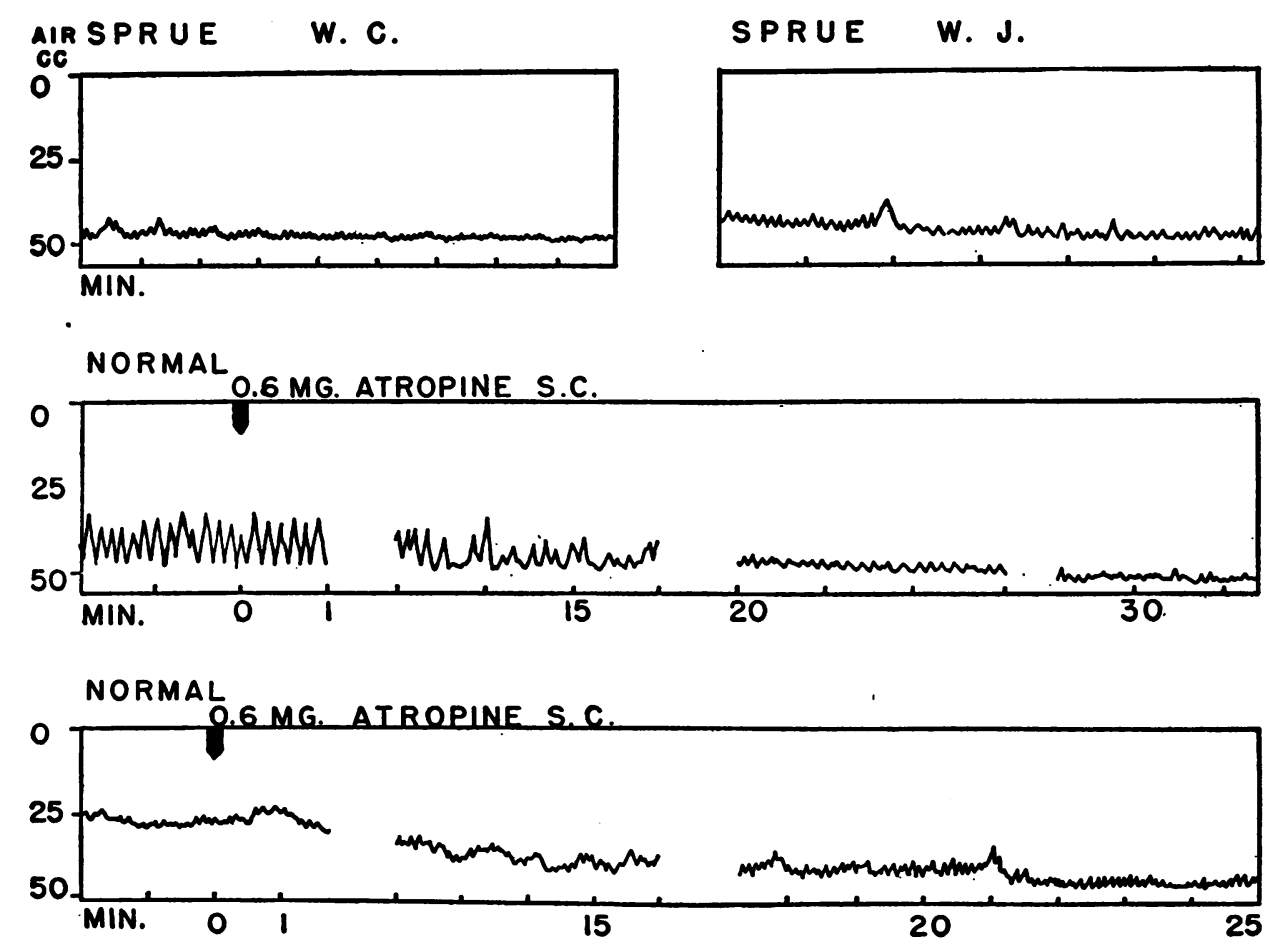

Fig. 1. Comparison of the Jejunal Motor Activity in Patients with Sprue and in Normal Atropinized Subjects 
On 4 occasions, an oral dose of 10 cc. of Navitol was given. After the vitamin A was administered, blood samples were usually taken at hourly intervals, during a period of 3 to 5 hours. Since the subjects were atropinized for less than 3 hours, further blood samples were considered unnecessary in evaluating the influence of atropine upon the absorption rate of vitamin A.

The levels of vitamin $A$ in the serum were determined according to the method of May et al. (4), and the formula of Yarborough and Dann (5) was used in converting the photoelectric colorimeter readings into International Units.

The subjects who received the test dose intra-enterically were intubated according to the method of Miller and Abbott (6), the position of the tube being determined by fluoroscopy. Records of the small intestinal motor activity were taken according to the method described by Ingelfinger and Abbott (7).

Atropine sulfate was given subcutaneously in 3 doses, the total amount being $1.4 \mathrm{mgm}$. or less in all but one experiment. For the most part, $0.6 \mathrm{mgm}$. was given 30 minutes before administering the vitamin $\mathrm{A}, 0.4 \mathrm{mgm}$. at the time of administration, and $0.4 \mathrm{mgm}$. one hour later. These dosages produced a dry mouth, but no other symptoms were experienced by the subjects.

Identical tests were carried out before and after atropinization on 5 of the 6 subjects. In the case of the sixth, a normal volunteer, 13 tests were done. In 8 of

TABLE I-a

Results of vitamin $A$ absorption tests-effect of atropine

\begin{tabular}{|c|c|c|c|c|c|c|c|c|c|}
\hline \multirow{2}{*}{ Subject } & \multirow{2}{*}{$\begin{array}{l}\text { Test dose } \\
\text { (I. U. of } \\
\text { vitamin A) }\end{array}$} & \multirow{2}{*}{$\begin{array}{l}\text { Where } \\
\text { administered }\end{array}$} & \multirow{2}{*}{$\begin{array}{c}\text { Total dose of atropine } \\
\text { (mgm.) }\end{array}$} & \multicolumn{6}{|c|}{ I. U. of vitamin A per $100 \mathrm{cc}$. of plasma } \\
\hline & & & & Fasting & 1 hour & 2 hours & 3 hours & 4 hours & 5 hours \\
\hline 1 & $\begin{array}{l}500,000 \\
500,000\end{array}$ & $\begin{array}{l}\text { Mouth } \\
\text { Mouth }\end{array}$ & $\begin{array}{c}0 \\
1.4\end{array}$ & $\begin{array}{r}94 \\
111\end{array}$ & & & $\begin{array}{l}504 \\
136\end{array}$ & 522 & $\begin{array}{l}952 \\
886\end{array}$ \\
\hline 2 & $\begin{array}{l}250,000 \\
250,000\end{array}$ & $\begin{array}{l}\text { Duodenum } \\
\text { Duodenum }\end{array}$ & $\begin{array}{c}0 \\
1.4\end{array}$ & $\begin{array}{r}83 \\
111\end{array}$ & & $\begin{array}{l}715 \\
152\end{array}$ & & $\begin{array}{l}890 \\
337\end{array}$ & 922 \\
\hline 3 & $\begin{array}{l}250,000 \\
250,000\end{array}$ & $\begin{array}{l}\text { Duodenum } \\
\text { Duodenum }\end{array}$ & $\begin{array}{c}0 \\
1.8\end{array}$ & $\begin{array}{l}102 \\
108\end{array}$ & $\begin{array}{l}116 \\
111\end{array}$ & $\begin{array}{l}218 \\
141\end{array}$ & $\begin{array}{l}277 \\
256\end{array}$ & & \\
\hline 4 & $\begin{array}{l}250,000 \\
250,000\end{array}$ & $\begin{array}{l}\text { Duodenum } \\
\text { Duodenum }\end{array}$ & $\begin{array}{c}0 \\
1.4\end{array}$ & $\begin{array}{l}69 \\
68\end{array}$ & & $\begin{array}{r}135 \\
90\end{array}$ & $\begin{array}{l}390 \\
153\end{array}$ & & \\
\hline 5 & $\begin{array}{l}250,000 \\
250,000\end{array}$ & $\begin{array}{l}\text { Duodenum } \\
\text { Duodenum }\end{array}$ & $\begin{array}{c}0 \\
1.4\end{array}$ & $\begin{array}{r}75 \\
104\end{array}$ & & $\begin{array}{l}190 \\
148\end{array}$ & $\begin{array}{l}207 \\
142\end{array}$ & & \\
\hline 6 & $\begin{array}{l}500,000 \\
500,000\end{array}$ & $\begin{array}{l}\text { Mouth } \\
\text { Mouth }\end{array}$ & $\begin{array}{c}0 \\
1.4\end{array}$ & $\begin{array}{l}103 \\
108\end{array}$ & & 114 & $\begin{array}{l}877 \\
147\end{array}$ & & $\begin{array}{r}935 \\
1,140\end{array}$ \\
\hline $6 a$ & $\begin{array}{l}250,000 \\
250,000\end{array}$ & $\begin{array}{l}\text { Duodenum } \\
\text { Duodenum }\end{array}$ & $\begin{array}{c}0 \\
1.4\end{array}$ & $\begin{array}{r}109 \\
82\end{array}$ & 144 & $\begin{array}{r}243 \\
84\end{array}$ & 88 & $\begin{array}{r}648 \\
90\end{array}$ & 518 \\
\hline $6 \mathrm{~b}$ & $\begin{array}{l}250,000 \\
250,000\end{array}$ & $\begin{array}{l}\text { Jejunum } \\
\text { Jejunum }\end{array}$ & $\begin{array}{c}0 \\
1.4\end{array}$ & $\begin{array}{l}96 \\
90\end{array}$ & 191 & $\begin{array}{r}300 \\
85\end{array}$ & $\begin{array}{l}334 \\
138\end{array}$ & $\cdot 242$ & \\
\hline $6 c$ & $\begin{array}{l}250,000 \\
250,000\end{array}$ & $\begin{array}{l}\text { Ileum } \\
\text { Ileum }\end{array}$ & $\begin{array}{c}0 \\
1.4\end{array}$ & $\begin{array}{l}103 \\
104\end{array}$ & $\begin{array}{r}123 \\
99\end{array}$ & 89 & $\begin{array}{l}428 \\
106\end{array}$ & $\begin{array}{l}470 \\
101\end{array}$ & \\
\hline
\end{tabular}

TABLE $1-b$

Effect of atropine and other agents

\begin{tabular}{|c|c|c|c|c|c|c|c|c|c|}
\hline 6 & $\begin{array}{l}250,000 \\
250,000 \\
250,000 \\
250,000\end{array}$ & $\begin{array}{l}\text { Duodenum } \\
\text { Duodenum } \\
\text { Duodenum } \\
\text { Duodenum }\end{array}$ & $\begin{array}{c}0 \\
\text { Emulsified in ox-bile solution. } \\
\text { Prostigmine } 0.5 \mathrm{mgm} . \\
1.4 \\
1.4 \begin{array}{c}\text { mgm. atropine emulsified in } 120 \\
\text { cc. fresh intestinal juice }\end{array}\end{array}$ & $\begin{array}{r}109 \\
85 \\
82 \\
87\end{array}$ & $\begin{array}{r}144 \\
85\end{array}$ & $\begin{array}{r}243 \\
231 \\
84 \\
103\end{array}$ & $\begin{array}{r}305 \\
88 \\
257\end{array}$ & $\begin{array}{r}648 \\
271 \\
\\
90 \\
538\end{array}$ & 518 \\
\hline 6 & $\begin{array}{l}250,000 \\
250,000 \\
250,000 \\
250,000 \\
250,000\end{array}$ & $\begin{array}{l}\text { Jejunum } \\
\text { Jejunum } \\
\text { Jejunum } \\
\text { Jejunum } \\
\text { Jejunum }\end{array}$ & $\begin{array}{c}0 \\
1.4 \\
1.4 \\
\text { with } 200 \mathrm{cc.} \text { water } \\
1.4 \\
\text { with } 180 \text { cc. intest. juice } \\
1.4 \\
\text { emulsified with } 85 \mathrm{cc.} \text { intest. juice }\end{array}$ & $\begin{array}{r}96 \\
90 \\
82 \\
98 \\
105\end{array}$ & $\begin{array}{r}191 \\
74 \\
125 \\
118\end{array}$ & $\begin{array}{r}300 \\
85 \\
74 \\
184 \\
142\end{array}$ & $\begin{array}{r}334 \\
138 \\
81 \\
328 \\
288\end{array}$ & $\begin{array}{l}242 \\
157\end{array}$ & \\
\hline
\end{tabular}




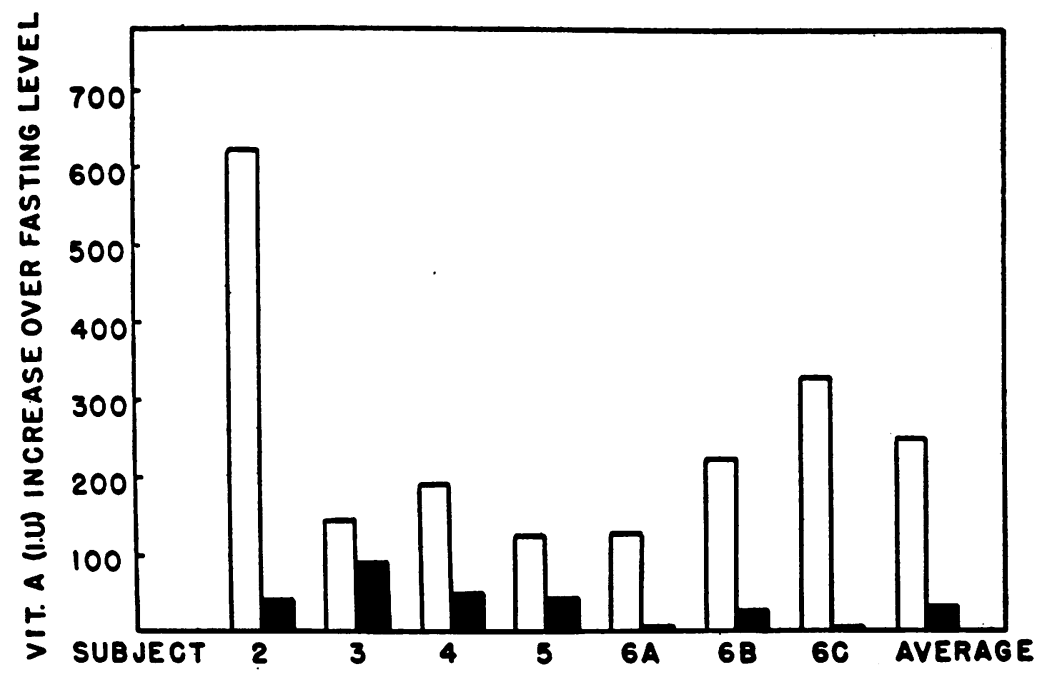

Fig. 2. Comparison of Vitamin A Increase in Unmedicated aNd Atropinized Subjects

Each of the first 7 white columns represents an average of the increase in plasma vitamin A levels, obtained 2 and 3 hours after the intra-intestinal injection of vitamin $\mathbf{A}$ in the unmedicated subject. Each black column represents the increase observed during the same period in the same subjects when atropinized. The last pair of columns is an average of the results obtained in the 7 pairs of experiments.

these tests, the Navitol was given at different intestinal levels, while 4 tests were performed to determine the effect of adding water (200 cc.) or small intestinal juices $(85,120$, and $180 \mathrm{cc}$.) to the test dose when subject 6 was atropinized. In one test, prostigmine was the only drug given to subject 6 , and the test dose was emulsified in a solution of dried ox-bile U.S.P. (2 grams in $100 \mathrm{cc}$. of water). The small intestinal juices were collected by syphonage through a Miller-Abbott tube, after the flow of juices was stimulated by the oral ingestion of a milk eggnog.

\section{RESULTS}

Table I shows that atropinization consistently depressed the rate with which vitamin A appeared in the plasma. In subject 6 , this was true whether the test substance was given by mouth, into the duodenum, into the jejunum, or into the high ileum. The greatest difference in the absorption rates before and after atropinization was evident in the plasma samples taken 2 to 3 hours after giving the test dose. In these samples, the vitamin A level in the unmedicated subjects showed an average increase of 254 I.U. of vitamin A over the fasting value, whereas the average increase in the same subjects treated with atropine was only 37 I.U. As is evident in Figure 2, however, considerable individual variation occurred.
In subject 6, the normal absorption rate of vitamin $A$ was not accelerated by emulsifying the test dose in the ox-bile solution and by administering prostigmine $(0.5 \mathrm{mgm}$.) When atropine was given to the same subject, its effect was not diminished by injecting $200 \mathrm{cc}$. of water into the jejunum immediately after injecting the test dose. When the test dose was given with varying amounts of fresh intestinal juice, however, the effect of atropine upon the absorption rate of vitamin A was partly decreased (Figures 3 and 4).

Two normal subjects who did not receive any Navitol were given $0.6 \mathrm{mgm}$. of atropine sulfate subcutaneously. Their plasma vitamin A values did not change appreciably in the next 4 hours.

\section{DISCUSSION}

When a test substance is given into the intestine, changes in the blood content of this substance reflect not only the rate of absorption, but also the rates of utilization, storage, and excretion. This holds true of the vitamin A absorption test as practiced by others and ourselves, but in the present experiments, the factors of utilization, storage, and excretion of the vitamin are 


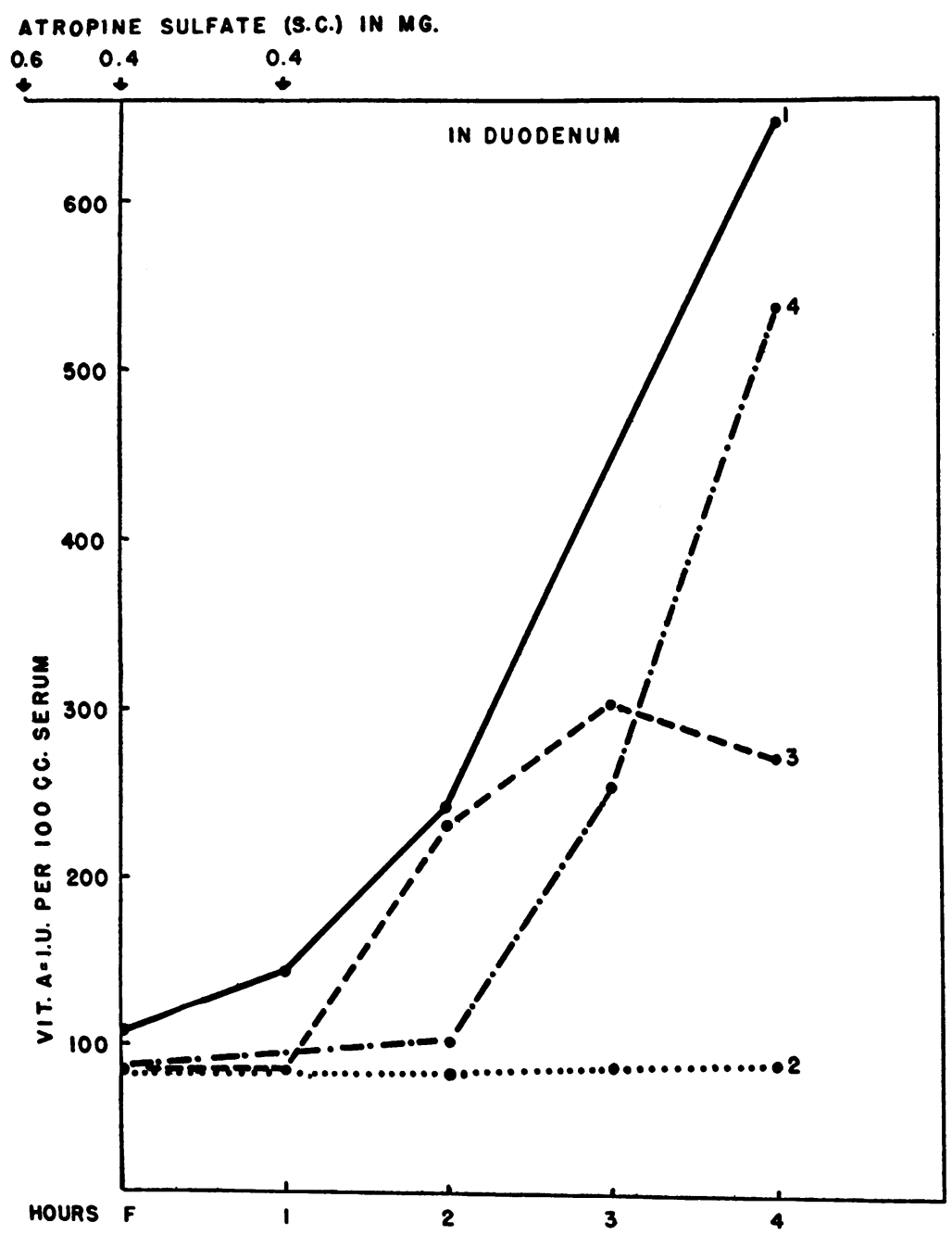

Fig. 3. Intraduodenal Vitamin A Absorption Tests in the Same SubJect : Effect of Adding Various Agents to the Test Dose

1. Normal. 2. After atropinization. 3. After administration of prostigmine. Test dose emulsified in ox-bile solution. 4. After atropinization. Test dose given with $120 \mathrm{cc}$. intestinal juice.

presumably constant in the same person and not affected by atropine. Hence, we feel justified in believing that the retarded appearance of vitamin $A$ in the plasma, following injections of atropine, results from the effect of this drug upon absorption.

How atropine delays the absorption of vitamin A from the gut is a difficult question to answer, especially since the exact mechanism involved in the absorption of the vitamin is unknown. According to Greaves and Schmidt (8), 4 out of 7 rats absorbed enough vitamin $A$ to maintain a normal vaginal epithelium after bile had been ex- cluded from the small intestine. On the other hand, May and McCreary (9) found that 3 infants with congenital atresia of the bile ducts exhibited a very low vitamin A absorption curve, and a similar phenomenon was noted by us in a patient who suffered from a total biliary fistula (10). May and McCreary (9) also obtained flat absorption curves of vitamin $\mathrm{A}$ in 7 children with pancreatic fibrosis. However, the evidence concerning the obligatory participation of bile or pancreatic ferments in the absorption of vitamin $\mathrm{A}$ is merely suggestive, not conclusive.

Goodman and Gilman (11) state that "The ac- 


\section{ATROPINE SULFATE (S.C.) IN MG.}

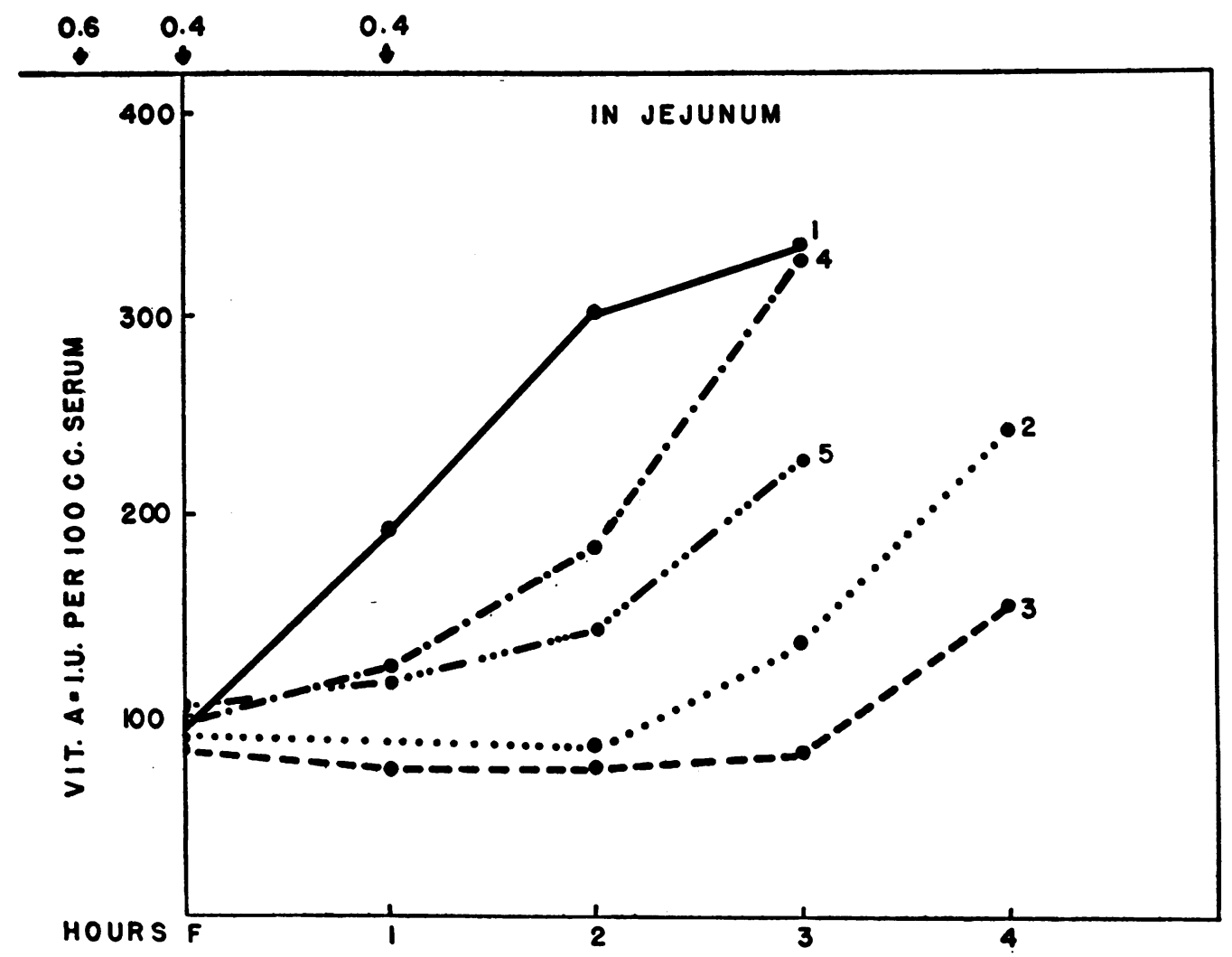

Fig. 4. Intrajejunal Vitamin A Absorption Tests in the Same Subject: Effect of Adding Various Agents to the Test Dose

1. Normal. 2. After atropinization. 3. After atropinization. Test dose given with 200 cc. water. 4. After atropinization. Test dose given with $180 \mathrm{cc}$. of intestinal juice. 5. After atropinization. Test dose emulsified with 85 cc. of intestinal juice.

tion of atropine on the secretions of the intestinal glands, pancreatic juice and bile is not significant." The relative importance of the vagal system and humoral agents in controlling the biliary and pancreatic secretions is, however, not sharply defined. Ivy (12) observed that the emptying of the cat's gall bladder was decreased but not abolished by a large dose of atropine ( 2 to $10 \mathrm{mgm}$.) and, in a review of the literature (13), concluded that atropine in man "has no effect or delays gall bladder emptying." A more recent study by Schube et al. (14) indicates that atropine delays the response of the human gall bladder to a fat meal.

In the study of pancreatic function, injections of acetyl-betamethylcholine have been found to stimulate the production of a pancreatic secretion which is richer in enzymes than that which appears after injections of secretin (15). The dominant role of the vagus in regulating the output of pancreatic enzymes has also been emphasized by Thomas (16). On the other hand, secretin has been found to be effective, even in the atropinized animal (17), and Comfort et al. (18) have found that the pancreatic lipase liberated in response to a meal was not markedly reduced by atropine.

In our experiments, the addition of freshlycollected intestinal juices to the test dose diminished the effect of atropine in delaying the absorption of vitamin A. It appears, therefore, that some of this delay is produced by an inhibition of the nervous stimuli controlling pancreatic and biliary secretions.

Several possibilities offer themselves in explanation of the fact that the administration of intestinal juices with the test dose merely diminished 
but did not abolish the effect of atropine upon the absorption rate. The intestinal juices, as given by us, may have been of insufficient quantity or of impaired quality. On the other hand, atropine may depress the absorption of vitamin $A$, not only by inhibiting intestinal secretions but also through some other mechanism. Dr. Stewart Wolf (19), who has noted that atropine produces a blanching of the gastric mucosa, has suggested that one such mechanism might consist of a change in intestinal blood flow, but as a rule, the effect of atropine on the circulation is considered to be slight (11).

Another possibility is that the inhibition of intestinal motility which follows atropinization may directly delay absorption. This hypothesis is attractive since in both the atropinized normal subject and in the patient with sprue, intestinal motility and the absorption of vitamin $\mathrm{A}$ are similarly depressed. We were, however, unable to obtain any direct evidence in support of such an assumption. An intrajejunal injection of water, which theoretically should disperse the test substance over a greater intestinal area, failed to diminish the effect of atropine; and an attempt to improve the purely mechanical factors of absorption by administering an emulsified test dose to a subject who had been given prostigmine did not augment the normal absorption rate. Very likely, the motility of the normal bowel offers optimum conditions for digestive and absorptive processes.

Kirsner and Palmer (20) stated that they, as well as a preponderance of the reports in the literature, favored the belief that atropine retards gastric evacuation. In spite of recent evidence to the contrary (21), we attempted to avoid this issue by injecting the test substance beyond the pylorus.

\section{CONCLUSIONS}

Atropine sulfate delays the appearance of vitamin $\mathrm{A}$ in the plasma after this vitamin has been placed in the small intestine of human subjects.

It appears that some of this delay is produced by an inhibition of the pancreatic and biliary secretions.

It is possible that the decreased intestinal motility which attends atropinization retards the absorption of the vitamin, but no direct evidence to substantiate this hypothesis is adduced by our data.

\section{BIBLIOGRAPHY}

1. Ingelfinger, F. J., and Moss, R. E., The motility of the small intestine in sprue. J. Clin. Invest., 1943, 22,345 .

2. Elsom, K. A., and Drossner, J. L., Intubation studies of the human small intestine. XVII. The effect of atropine and belladonna on the motor activity of the small intestine and colon. Am. J. Digest. Dis., 1939, 6, 589.

3. May, C. D., and McCreary, J. F., The glucose tolerance test in celiac disease. J. Pediat., 1940, 17, 143.

4. May, C. D., Blackfan, K. D., McCreary, J. F., and Allen, F. H., Clinical studies of vitamin $A$ in infants and in children. Am. J. Dis. Child., 1940, 59, 1167.

5. Yarbrough, M. E., and Dann, W. J., Dark adaptometer and blood vitamin A measurements in a North Carolina nutrition survey. J. Nutrition, 1941, 22, 597.

6. Miller, T. G., and Abbott, W. O., Intestinal intubation: A practical technique. Am. J. M. Sc., 1934, 187, 595.

7. Ingelfinger, F. J., and Abbott, W. O., Intubation studies of the human small intestine. XX. The diagnostic significance of motor disturbances. Am. J. Digest. Dis., 1940, 7, 468.

8. Greaves, J. D., and Schmidt, C. L. A., On the absorption and utilization of carotene and vitamin $A$ in choledochocolonostomized vitamin A deficient rats. Am. J. Physiol., 1935, 111, 492.

9. May, C. D., and McCreary, J. F., The absorption of vitamin A in celiac disease. J. Pediat., 1941, 18, 200.

10. Unpublished observation.

11. Goodman, L., and Gilman, A., The Pharmacological Basis of Therapeutics. Macmillan Co., New York, 1941.

12. Ivy, A. C., Factors concerned in the evacuation of the gall bladder. Medicine, 1932, 11, 345.

13. Ivy, A. C., The physiology of the gall bladder. Physiol. Rev., 1934, 14, 1.

14. Schube, P. G., Myerson, A., and Lambert, R., The effect of benzedrine, benzedrine and atropine, and atropine on the gall bladder. Am. J. M. Sc., 1939, $197,57$.

15. Comfort, M. W., and Osterberg, A. E., Pancreatic secretion in man after administration of different stimulants: A comparative study. Am. J. Digest. Dis., 1941, 8, 337.

16. Thomas, J. E., The effect of nervous and hormonal stimulation on zymogen secretion. Federation Proc., 1942, 1, 261.

17. Barrington, E. J. W., The influence of secretin on pancreatic secretion in the cat. J. Physiol., 1941, $100,80$. 
18. Comfort, M. W., Osterberg, A. E., and Priestly, J. T., External pancreatic fistula: Report of a case with physiologic observations. Am. J. Digest. Dis., 1943, 10, 7.

19. Wolf, S., Personal communication.

20. Kirsner, J. B., and Palmer, W. L., The effect of various antacids on the hydrogen-ion concentration of the gastric contents. Am. J. Digest. Dis., 1940, $7,85$.

21. Folley, J. H., and Abbott, W. O., The influence of certain commonly used drugs on the rate of gastric emptying in the normal subject as determined by an intubation technique. Am. J. Digest. Dis., 1942, 9, 202. 